Bryn Mawr College

Scholarship, Research, and Creative Work at Bryn Mawr College

Sociology Faculty Research and Scholarship

Sociology

2008

\title{
Researching African Women and Gender Studies: New Social Science Perspectives
}

\author{
Akosua Adomako Ampofo \\ Josephine Beoku-Betts \\ MaryJ. Osirim \\ Bryn Mawr College, mosirim@brynmawr.edu
}

Let us know how access to this document benefits you.

Follow this and additional works at: http://repository.brynmawr.edu/soc_pubs

Part of the Sociology Commons

\section{Custom Citation}

Ampofo, Akosua Adomako, Josephine Beoku-Betts and Mary J. Osirim. "Researching African Women and Gender Studies: New Social Science Perspectives." African and Asian Studies 7 (2008): 327-341.

This paper is posted at Scholarship, Research, and Creative Work at Bryn Mawr College. http://repository.brynmawr.edu/soc_pubs/8

For more information, please contact repository@brynmawr.edu. 


\section{Researching African Women and Gender Studies: New Social Science Perspectives Special Issue of African and Asian Studies Co-editors - Akosua Adomako Ampofo (University of Ghana) Josephine Beoku-Betts (Florida Atlantic University) and Mary Johnson Osirim (Bryn Mawr College)}

\section{Introduction}

Over the past two decades, the discipline of feminist and gender studies has changed rapidly as issues of difference, power, knowledge production and representation are contested, negotiated, and analyzed from multiple and shifting sites of feminist identities. While previously a homogenized notion of "women" was taken as given, emphasizing commonalities over differences, reconceptualizations of feminism have shifted the focus to issues of race, class, sexuality, ability, ethnicity, nationality, and globalization, stressing the interconnectedness as well as differences of these experiences. In the field of feminist and gender studies it is now clearly understood that theorizing women's experiences from these multiple angles of vision generates new questions, issues, and interpretations (e.g., Hill Collins, 2000; Bell Hooks, 1988; Mohanty, 1991, 2003), thereby broadening and complicating analysis of the historical, political, economic, and cultural forces that shape women's differentiated lives and produce particular forms of individual and collective action. Among the key trends and transformations that have significantly impacted feminist scholarship are transnational and Black feminism. Both perspectives theorize across national boundaries and emphasize the significance of historical legacies and contemporary political, economic, racial, and cultural processes that intersect and shape women's lives across time and space, including the particular agendas of diverse feminist movements. Also, both 
challenge the complicity of western feminism on issues of racism and colonialism, focusing instead on the politics of solidarity and anti-capitalist social movements (Mohanty, 2000).

Transnational feminism gained resonance with the growth of globalization and examines the impact of these complex conditions on women's lives from a global and interdisciplinary perspective, while addressing new forms of international alliances and networks "enabled by new media and technologies, as well as contemporary political, economic, and cultural movements" (Grewal and Kaplan, 2006; xx11.) Black feminist theory is especially concerned with the significance of race as a fundamental organizing principle interacting with other forms of structured inequality to shape the social construction of gender and situated location of social groups (Baca Zinn and Thornton Dill, 1996). It also takes account of how race interacts across national and transnational boundaries to structure relations between women and men and among women, and to produce oppression and opportunity or privilege. By problematizing emergent feminist scholarship within Africa and the African diaspora, Black feminist epistemology provides an opportunity to address commonalities and differences and to bring important theoretical and empirical insights from these locations to the dimensions and forms of globalization, migration, and feminist movements and agendas.

In sum, both of these perspectives provide the tools for new possibilities and challenges for a broader growth of feminist knowledge production and activism, based on anti-racist, anti-capitalist, and anti-colonialist agendas. They form the backdrop for new understandings in the field of women and gender in Africa and the Diaspora, and bring to the table the significance of this body of knowledge in global feminist scholarship. This 
special issue contributes to existing and new areas of knowledge production in African gender studies and demonstrates African women's agency in transforming their societies, states, and economies on the continent and in the Diaspora. The articles demonstrate collaboration across academic fields and across geographical spaces, including works from African gender scholars based in the global north. In their locations within academies on the continent and in the United States, the co-editors further build bridges among African and African Diasporic researchers in the development of new areas of global feminist scholarship.

In the following sections some of the theoretical and analytical positions addressed in African gender scholarship are discussed, emphasizing the need to recognize that there are many cultures, multiple and complex identities that need to be studied and understood in Africa and its Diaspora, such as the growing focus on representation, identities, subjectivities, and sexualities, discourses on democracy, governance, and human rights, as well as geographical and linguistic diversities. This is followed by a review of the particular themes addressed in the articles such as: gender studies scholarship from Lusophone and North Africa; transforming the state through politics, civil society, and social movements; work and development; and identities as migrants, transnationals, and gendered subjects.

Theoretical and Analytical Themes in African Gender Scholarship

African gender scholarship charts new theoretical and empirical ground and brings distinctive and important perspectives to transnational and Black feminist theorizing and teaching. A specific aim of this body of scholarship is to enhance intellectual exchanges among scholars and to make research more relevant for activists. 
In this regard, the establishment of nationally and regionally based programs in women's and gender studies tailored towards stimulating intellectual engagement through the development of teaching, research and activist projects forms the underlying basis of this objective. Two noted examples are The Council for the Development of Social Science Research in Africa's (CODESRIA) annual Gender Institute and the University of Cape Town's African Gender Institute (AGI).

Concerns over culture and identity are frequently found in African centered feminist responses to work by scholars based in the global North, as well as Afrocentrists and Pan-Africanists or African Nationalists. In responding to scholars in the global North many African centered feminists reject what they view as the objectification and commodification of African women and the notion of a feminist sisterhood, from which tensions have emerged between the groups (e.g., Beoku-Betts and Njambi, 2005). Fueled by indignation over the marginalization of African gender scholars in the production and dissemination of feminist knowledge production, Obioma Nnaemeka convened the first international conference on Women in Africa and the African Diaspora (WAAD) at the University of Nigeria, Nsukka in Nigeria in 1992 (Nnaemeka, 1998). The controversies that erupted around the naming and conceptualization of women's oppression are a testimony to important differences that emerged from the discussions. Tensions arose between some African American researchers and African and North American scholars who organized this conference around the use of such terms as "feminism" and "womanism." Based on their different locations in the global system and distinctions in their experiences of intersectionality, several African American women objected to the use of the term "feminist" as opposed to "womanist" in describing their perspectives and 
their lived experience, since they associated the former term with a movement which they viewed as Eurocentric. These divisions threatened the creation of the very sisterhood that African American scholar/activists hoped to forge with their African counterparts. The responses to Afrocentric perspectives have tended to seek to release discourses on women and gender relations from essentialist paradigms and the invisibility imposed by descriptions of a common Africa in anti-colonialist discourses (ref).

At the same time, African-centered feminist scholarship has had to address the problem of whether to accept some of the concepts produced in the global north, and how to name the understandings of African realities so that they remain African-centered as well as "feminist". For example, various conflicts and contestations have emerged around the relevance and application of concepts related to women's studies and gender analysis. Given the linguistic diversity of the continent, many African scholars have to work in languages that are not originally their own. For example, Oyewumi (1997) has famously challenged the usefulness of gender as an analytic concept for Africa. She argues that among the Yoruba, language is gender-neutral and that social roles and relations between men and women are based primarily on the notion of seniority, so that men and women can assume powerful positions by virtue of their age and seniority within a family. Oyewumi's work has been widely critiqued for generalizing from the Yoruba to Africa, and for the simplistic notion that the absence of biologically-based gender markers in a language means that notions of gender hierarchies do not exist (Bakare-Yususf, 2004). An important contribution to theorizing, resulting from such tensions, is the recognition that there is no generic "African" woman (or man), and that African women's and men's lives, like those of all people, are fluid and change over time; 
in addition their lives are affected by globalization, race, class, location, kinship, marriage, age, and a host of other factors.

Although, not evenly spread nor mutually exclusive, there are several key issues of concern in African gender scholarship on the continent and among African Diaspora feminist scholars and activists. Evident particularly in the southern Africa region are explorations and theorizing around sexualities, including homosexualities, areas that hitherto experienced silencing. For example the edited volume by Roscoe and Murray (2001) and the work of Gays and Lesbians in South Africa (GLASS) provide anthologies of same-sex encounters that testify to a wide range and complex arena of sexual relations. In the West and East Africa regions the economy and effects of neo-liberal economic reforms as well as women's representation in government and civil society remain strong. Feminist researchers, such as Pereira (2003) and Steady (2006) note that while poor and low-income African women have faced the most deleterious effects of globalization in the form of structural adjustment programs (SAP's), these women continue to resist such policies in organizing against multinational corporations and the state. Scholars of North Africa based in the region and in the global north, pay more attention to issues of religion and culture. For example, Charrad (2001) makes a major contribution to the theoretical debates regarding Islam and women's rights by arguing that we need to consider the relationship between the state and kin groups/patriarchal communities that shaped the nation and gender policy. In Tunisia, where the power of kin groups was weaker than among their counterparts in other parts of the Mahgrib, more progressive family law developed, which advanced women's rights.

There are also areas that cut across all regions, such as economics and politics. 
Across the continent, recent efforts to promote gender equality under the formal agreement of the New Partnership for African Development (NEPAD) have been criticized for failing to identify and implement specific gender policies and strategies. This is clearly demonstrated in the lack of political willingness on the part of political leaders to promote changes in customary marriage laws, property inheritance, and closing the gender gap in school enrollments at all levels (Longwe, cited in Stromquist 2007).

As noted by Steady (2006), African women have long devoted time to confronting economic and political challenges. They have been deeply involved in liberation struggles even if their presence has largely been undocumented. Recent studies pay more attention to the complex relationship that women have with the state, issues of good governance, the nature of the state, and questions of participatory democracy and citizenship. They highlight the nature of the relationship between the rise of liberal democracies, their current practices, women's marginalization, and social and popular movements. The work of civil society organizations, such as ABANTU for development, has been influential in highlighting women's presence, or lack thereof, in government and state structure. In 2003, ABANTU's work linked research with activism when it initiated the formation of the Coalition on the Women's Manifesto. The manifesto sets out critical issues of concern to women in Ghana and makes demands for addressing them of government and other political parties (Abantu 2003). As it becomes clear from Gouws' study on women's reperesentation in the South African electoral system of 2004, the question of women and politics is about more than numbers (Gouws 2004). This was made starkly evident in recent discussions on the GWS list serve in which many South African women, particularly, expressed deep dissapointment about the 
ANC's Women's League's support for Jacob Zuma as leader of the ANC. ${ }^{1}$. The dynamism of civil society organizations is also reflected in the wealth of advocacy-based research, especially in the areas of violence, rights, and relations with the state. Much of this work has formed the basis for development of theorizing with a transformative agenda and, in turn, found its way into pedagogy and scholarship. For example, in 2006 the African Feminist Forum was launched in Accra to bring scholars and activists together to push transformative agendas in their countries.

Since the 1990's, a new interest in masculinities has developed in Africancentered gender scholarship. This emergent body of work has been influenced by discourses in the global north, particularly Connell's (1995) notions of so-called hegemonic masculinities. Research in masculinities is manifested in analyses of the impacts of colonialism and, particularly in Southern Africa, the effects of apartheid and racism on creating a certain kind of man (c.f. the volume edited by Schefer et. al. 2007). This research has not been without its contestations. A general perception is that no sooner were women's concerns finally receiving attention in scholarly discourses than were men once again seeking centre stage. Nonetheless, the study of masculinities has been significant in the areas of health (AIDS) and violence (particularly domestic violence and in situations of conflict). Recent studies point to the importance of a more nuanced appreciation of men's diverse experiences with "sensitivity to processes of subjectivity and context" (Gibson and Lindegaard 2007: 144) and processes of social change, men's social relations with each other and different categories of women, and the ways in which they cope with these changing relations. Gibson and Lindegaard's work

1 Jacob Zuma was accused and later acquitted of rape by the 31-year old daughter of a deceased comrade. During his trial he conceded that he had (consensual) "unprotected" sex with his accuser, whom he knew to be HIV+, and that he had a shower after intercourse to reduce the risk of contracting AIDS. 
was one of several ethnographic studies that emerged from a meeting on "Boys and Masculinity" that took place at the University of the Western Cape in January 2005 and led to the book Fom Boys to Men (Schefer at al. 2007). From Boys to Men acknowledges the multiple versions of masculinity including resistances, and even challenges to socalled hegemonic forms.

In the area of methods, contemporary African gender scholars, as their African Diaspora counterparts, continue to prefer qualitative approaches, particularly interviews, life stories and other narrative forms. Qualitative analytical approaches are viewed as more relevant to the realities and experiences of Africans and focused on political commitment and responsibility towards Africa and its Diaspora. For example, a newly formed international Research Project Consortium on Pathways to Women's Empowerment and which includes members from Ghana, Nigeria, Sierra Leone, Egypt, Brazil, Bangladesh, Afghanistan, and the UK, privileges qualitative over quantitative methods. There is also growing interest in the use of various forms of historical methods, such as oral history and autobiographical and biographical studies which have enabled women of different classes to bring their own voices to the analysis of their experiences (e.g., Ngaiza and Koda 1991; Bozzoli 1991) and helped redefine conventional understandings of various historical events and processes (Lewis 2002). These studies show, for instance, that the now challenged tradition in the global north of dichotomizing social space and gender into public versus private spheres, has never accurately reflected the historical and cultural realities of the African experience. Many of the life history studies show the distinctive ways in which women exercised agency in the pre-colonial and colonial periods by subverting conventional understandings of appropriate gender 
relations.

The articles in this special issue contribute to existing and new areas of knowledge production in the field of African gender studies and demonstrate African women's agency in transforming their societies, states and economies on the continent and in the Diaspora. While conversant with postmodernist discourses on difference, African gender scholars exercise caution against over-dependency on theoretical approaches that are fragmented and not integrated into wider political struggles and public debates that unify and create space for dialogue on historical, political and economic realities underpinning women and gender issues in the contemporary African experience (Nzomo 1998: 13). Marxist and anti-imperialist analyses have been similarly criticized for their dismissive and hostile treatment of feminists and issues of gender in the effort to emphasize the importance of economic class contradictions. (Imam 1997: 12). On the whole, while postmodernist and Marxist paradigms have both proved useful either in emphasizing issues of class or difference their failure to fully explore certain aspects of the relationship with women and gender lead them to produce biased and borrowed knowledge that mask existing gender subordination.

The papers are written by scholars from a wide range of social science fields, including anthropology, history, sociology, political science, and women's studies. At the same time, these works explore cutting-edge interdisciplinary issues, such as genderbased violence, transnationalism and the "gendering" of information technology and also apply feminist qualitative methods to case studies, participant-observation and in-depth interviewing to produce new scholarship in gender studies. Thus, these works chart new ground in both theoretical and empirical research on African women. This special issue 
also demonstrates collaboration across academic fields and across geographical spaces, including works from gender studies scholars based in Africa and the global north. In their locations within academies on the continent and in the United States, the co-editors further build bridges among African and African Diasporic researchers in feminist scholarship and in the development of a new Pan-Africanism.

While each of these articles makes a unique and important contribution to African gender studies, they also share some common themes: delineating women's contributions to feminist and gender studies scholarship in Lusophone and North Africa; understanding women's varied roles in the state, civil society and social movements; exploring women's contributions to socio-economic development on the continent and in the Diaspora; and examining African women's and men's complex identities as migrant populations, gendered subjects and transnationals.

\section{Gender Studies Scholarship from Lusophone and North Africa}

Sheldon, Rodrigues and Sadiqi review the major contributions of African feminist researchers in the former Portuguese colonies and in the Maghrib to the development of gender studies scholarship and programs in these regions. Building on issues raised in the UN Platform for Action from the Beijing Conference in 1995 and as demonstrated by Adomako Ampofo, Beoku-Betts, Njambi and Osirim (2004) for the Anglophone region, scholars in Lusophone and North Africa have made significant contributions to the debates in such areas as health, education, gender-based violence and globalization. Sheldon, Rodrigues and Sadiqi explore these areas and expand the discussion beyond Beijing to consider African women's studies of marriage and family, reforms in family law, sexuality and the transformation of the state in their regions. While these reviews 
share some common themes with Mama's (1996) and Lewis' (2002) reviews of feminist scholarship on African women, such as in exploring health, education and political development, Sheldon, Rodrigues and Sadiqi break new ground in focusing on populations from understudied geographical regions and linguistic groups, as well as in analyzing works by African researchers based on the continent.

\section{Transforming the State through Politics, Civil Society and Social Movements}

Over the past two decades, African women have made major strides in political office-holding and in advancing gender-equality, human rights and democratization in African states. Earlier feminist studies of African states have recognized the significant increase in the number of women in political positions as a result of quota systems, state feminism/femocracy and other forms of national gender machinery (Mama 1995; Tamale 1999; Dambe 2000; Ahikire 2004; Hassim 2006; Ibrahim 2004). As observed by Tsikata (2001), Wing (2002) and Tripp (2004), among others, Day and Gouws acknowledge the importance of these mechanisms in advancing women's rights, but also contend that political office-holding alone is insufficient in addressing gender inequality- civil society organizations are also critical. Through the concept, "bottom-power," Day explores how male power confronts women politicians and grassroots activists in striving for human rights and gender equity in Sierra Leone today. Ratele further contributes to the debates around male privilege and power in the state and society through illustrating how "ruling masculinity" is a social construction.

In addition to office-holding and the creation of gender machinery, Gouws argues that women's movements employing globalization as a central construct are also essential if gender equality is to be realized in southern Africa. She further acknowledges that in 
states racked by political instability and poverty, transnational feminist movements (as discussed by Moghadam 2005) are needed to foster equality. The importance of social movements to achieve women's rights are especially highlighted in Adomako Ampofo's study, which demonstrates how the mobilization of civil society organizations, in some cases across gender lines, led to the passage of Domestic Violence legislation in Ghana. Such efforts are also evident in the Diaspora where Osirim demonstrates how African women's leadership of civil society groups addresses the needs of immigrants, contributes to the development of a new pan-Africanism and revitalizes civil society in low-income areas.

\section{Work and Development}

Much of the feminist scholarship that explores African women's roles in work and development had focused on their concentration in agriculture and the microenterprise sector of the economy (Clark 1994; Adomako Ampofo 2007; Mama 1996; Robertson 1997; Darkwah 2002, 2007; Osirim 2003, 2007). Through the use of feminist case studies, Beoku-Betts expands our conceptions of the location and contributions of African women in the labor market by examining their roles as scientists, both locally and globally. Specifically, she explores how intersectionality shapes the concerns and priorities which Sierra Leonean women scientists bring to the process of scientific knowledge production and the contributions that they make to the development of their nation and the global scientific community. In investigating the roles of African women immigrants as entrepreneurs and community leaders, Osirim illustrates that they are major contributors to urban renewal in the northeastern US. On the other hand, Ratele illustrates how unemployment and the failures of development lead to a crisis of 
masculinity for some African men.

Identities as Migrants, Transnationals and Gendered Subjects

The significant expansion of scholarship on immigration and in gender studies has spawned increased attention on the development of identities. Recent immigrants from the Global South now living in the northern hemisphere increasingly identify themselves as transnationals - populations who have strong ties to both their home and host societies (Foner, 2001; Stoller, 2002). These transnationals maintain relationships with their home countries through remittances, frequent visits, and phone, mail and electronic communications. Much of the literature on Diasporic populations and Pan-Africanism, have paid scant attention to the roles of gender and class in creating distinctly different immigration experiences for women from the Global South (Reddock 2007). Feminist studies have revealed, however, that the process of migration is gendered - women experience significant disjunctions in the host societies between their educational attainment and the occupations that they obtain and their transitions are especially difficult due to race and gender discrimination, the loss of extended family support and other forms of social capital (Purkayastha, Raman and Bhide 1997; Yesufu 2005; Davies 2007). While Osirim also notes the major role that intersectionality occupies in the experiences of African women immigrants and their identity as transnationals, her work reveals that unlike their male counterparts, their gaze is firmly focused on the development of communities in the Diaspora. Her work further contributes to the dialogue on feminist transnationalism begun at the conference, "Gendering the Diaspora, Race-ing the Transnational" held at Duke University in 2005 (Reddock 2007).

Migrant identities also describe the experiences of women in Senegal who seek an 
escape from their daily lives in cyber cafes. Venables examines the experiences of these women engaged in both geographical and virtual migration - they move from poor rural areas to the city in an effort to escape poverty and secure a better future through internet dating. Finally, in exploring gendered identities, Ratele defines "ruling masculinities" as fluid, practices of power that are context-specific. Recognizing that power is a major component of masculine identities, he enables us to more fully understand how men who do not occupy positions of dominance in the labor market, the age spectrum and/or in their physical attributes are facing a crisis of masculinity which often leads to higher rates of gender-based violence, HIV/AIDS and poverty.

\section{Works Cited}

Adomako Ampofo, Akosua. "My Cocoa Is between My Legs: Sex as Work among Ghanaian Women," in Women's Labor in the Global Economy: Speaking in Multiple Voices, ed. Harley. New Brunswick: Rutgers University Press, 2007, 185-205.

Adomako Ampofo, Akosua, Josephine. Beoku-Betts, Wairimu. Njambi and Mary Osirim. "Women and Gender Studies in English-Speaking Sub-Saharan Africa," Gender \& Society 18, no. 6, 2004: 685-714.

Ahikire, Josephine. “Towards Women's Effective Participation in Electoral Processes: A Review of the Ugandan Experience.” Feminist Africa, Issue 3, 2004. http://www.feministafrica.org/index.php/towards-womens-effective

Bakare-Yusuf, Bibi. "Yorubas don't do Gender: A Critical Review of Oyeronke Oyewumi's The Invention of Woman..." African Gender Scholarship, 2004: 61-81.

Barriteau, V. E. "The Relevance of Black Feminist Scholarship: A Caribbean Perspective." Feminist Africa, Issue 7, 2006: 9-31. http://www.feministafrica.org/index.php/towards-womens-effective

Beoku-Betts, Josephine and Wairimu Ngaruiya Njambi. "African Feminist Scholars in Women's Studies: Negotiating Spaces of Dislocation and Transformation in the Study of Women." Meridian 6, no.1., 2005:113-132.

Bozzoli, B. Women of Phokeng: Consciousnes, Life Strategy and Migrancy in South Africa: 1900-1983. Johannesburg: Ravan, 1991.

Charrad, Mounira. States and the Women's Rights: The Making of Postcolonial Tunsia, 
Algeria and Morocco. Berkeley: University of California Press, 2001.

Clark, Gracia. Onions are My Husband: Survival and Accumulation by West African Market Women. Chicago: University of Chicago Press, 1994.

Cornell, R. W. Masculinities. Cambridge: Polity Press, 1995.

Crenshaw, K. "Mapping the Margins: Intersectionality, Identity Politics, and Violence against Women of Color." Stanford Law Review 43, July 1991.

Dambe, Regina Thea Maaswai. The National Machinery for the Advancement of Women: The Botswana Experience. Accra North, Ghana: Third World Network Africa, 2000.

Darkwah, Akosua. "Trading Goes Global: Market Women in an Era of Globalization." Asian Women 15, 2002: 31-49.

Darkwah, Akosua. "Work as a Duty and as a Joy: Understanding the Role of Work in the Lives of Ghanaian Female Traders of Global Consumer Items," in Women's Labor in the Global Economy: Speaking in Multiple Voices, ed. Harley. New Brunswick: Rutgers University Press, 2007, 206-220.

Davies, Carole Boyce. "Caribbean Women, Domestic Labor and the Politics of Transnational Migration," in Women's Labor in the Global Economy: Speaking in Multiple Voices, ed. Harley. New Brunswick: Rutgers University Press, 2007, 116133.

Foner, Nancy, ed. New Immigrants in New York. New York: Columbia University Press, 2001.

Gibson, Diana and Marie Rosenkrantz Lindegaard. "South African Boys with Plans for the Future: Why a focus on dominant discourses tells us only part of the story," in From Boys to Men: Social constructions of masculinity in contemporary society, eds. T. Schefer, K. Ratele, A. Strebel, N. Shabalala, and R. Nuikema. Capetown: University of Cape Town, 2007, 128-144.

Gouws, Amanda. "Rethinking Development from a Gender Perspective." Codesria Bulletin, nos. 3 \& 4, 2005: 24-26.

Grewal, I. and C. Kaplan. An Introduction to Women's Studies: Gender in a Transnational World. New York: McGraw Hill, 2006.

Hassim, Shireen. Women's Organizations and Democracy in South Africa - Contesting Authority. Scottsvile: University of KwaZulu Natal Press, 2006.

Hill Collins, P. Black Feminist Thought: Knowledge, Consciousness, and 
Empowerment. New York: Routledge, 2000.

Hooks, B. Talking Back: Thinking Feminist, Thinking Black. Boston: Southend Press, 1988.

Ibrahim, Jibrin. "The First Lady Syndrome and the Marginalisation of Women from Power: Opportunities or Compromises for Gender Equality." Feminist Africa, Issue 3, 2004. http://www.feministafrica.org/index.php/first-lady-syndrome

Imam, Ayesha, Amina Mama, and Fatou Sow. Engendering African Social Sciences. Dakar: CODESRIA Book Series, 1997.

Lewis. Desiree. "Review Essay: African Feminist Studies: 1980-2002. Gender and Women's Studies Africa.", 2002. http://gwsafrica.org/knowledge/africa

Longwe, S. "NEPAD: Reluctance to Address Gender Issues." in Nelly Stromquist, “ Higher Education in Africa and Latin America: Comparative Insights from Globalization and Gender Perspectives," in Women and Higher Education in Africa, edited by N'Dri Assie-Lumumba, Ohio: CEPPARED, 2007:405-442.

Mama, Amina. "Feminism or Femocracy? State Feminism and Democratization in Nigeria." Africa Development 20, Issue 2, 1995: 37-58.

Mama, Amina. Women's Studies and Studies of Women in Africa During the 1990s. Working Paper Series. Dakar: CODESRIA, 1996.

Moghadam, Valentine. Globalizing Women: Transnational Feminist Networks. Baltimore: The Johns Hopkins University Press, 2005.

Mohanty Talpade, C. "Cartographies of Struggle: Third World Women and the Politics of Feminism," in Third World Women and the Politics of Feminism, eds. A. Russo and L. Torres. Bloomington: Indiana University Press, 1991.

Feminism without Borders: Decolonizing Theory, Practicing Solidarity. Durham and London: Duke University Press, 2003.

Mwangola, Mshai. "Looking Back, Moving Forward: Reflections on Forum '85" Codesria Bulletin, Special Issue: The African Woman. Dakar, CODESRIA, 2006: 6-7.

Ngaiza, M. and B. Koda. The Unsung Heroines: Women's Life Histories from Tanzania. Dar es Salaam: Research and Documentation Project, 1991.

Nnaemeka, Obioma. "This Women's Studies Business: Beyond Politics and History (Thoughts on the First WAAD Conference)," in Sisterhood, Feminisms and Power, ed. O. Nnaemeka. Trenton: Africa World Press, 1998, 351-386. 
African Gender Studies: A Reader, ed. O. Oyewumi. New York: Palgrave Macmillan, 2005.

Nzomo, Maria. "Engendering Democraization in Kenya: A Political Perspective.” in Democratic Change in Africa:Women's Perspective, edited by Wanjiku MukabiKabira, Jacqueline Adhaimbo-Oduol, and Maria Nzomo, Nairobi, Kenya: AAWORD.

Osirim, Mary Johnson. "Carrying the Burdens of Adjustment and Globalization: Women and Microenterprise Development in Urban Zimbabwe." International Sociology 18, no. 3, 2003: 535-558.

Osirim, Mary Johnson. "Creatively Coping with Crisis and Globalization: Zimbabwean Businesswomen in Crocheting and Knitting," in Women's Labor in the Global Economy: Speaking in Multiple Voices, ed. Harley. New Brunswick: Rutgers University Press, 2007, 134-157.

Oyewumi, Oyeronke. The Invention of Women: Making an African Sense of Western Gender Discourses. Rochester: University of Minnesota Press, 1997.

Pereira, Charmaine. "Configuring 'Global', 'National' and 'Local' in Governance Agendas in Nigeria," Social Research 69, no. 3, 2003: 781-804.

Purkayastha, Bandana, Shyamala Raman and Kshiteeja Bhide. "Empowering Women: SNEHA's Multifaceted Activism," in Dragon Ladies: Asian American Feminists Breathe Fire, ed. Shah. Boston: South End Press, 1997, 100-107.

Reddock, Rhoda. "Editorial: Diaspora Voices." Feminist Africa, Issue 7, 2007. http://www.feministafrica.org/index.php/editorial-6

Robertson, Claire. Trouble Showed the Way: Women, Men and Trade in the Nairobi Area, 1890-1990. Bloomington: Indiana University Press, 1997.

Roscoe, Will and Stephen Murray, eds. Boy-Wives and Female Husbands: Studies of African Homosexualities. New York: Palgrave Macmillan, 2001.

Schefer, Tammy, Kopano Ratele, Anna Strebel, Nokuthula Shabalala, and Rosemarie Nuikema, eds. From Boys to Men: Social constructions of masculinity in contemporary society. Capetown: University of Cape Town Press, 2007.

Stoller, Paul. Money Has No Smell: The Africanization of New York City. Chicago: The University of Chicago Press, 2002.

Tamale, Sylvia. "Towards Legitimate Governance in Africa: The Case of Affirmative Action and Parliamentary Politics in Uganda," in Legitimate Governance in Africa, eds. Quashigah and Okafor. Amsterday: Kluwer Law International, 1999. 
Tamale, Sylvia. When Hen Begisn to Cry: Gender and Parliamentary Politics in Uganda. Boulder: Westview Press, 1999.

Thornton Dill, Bonnie and Maxine Baca Zinn. "Theorizing Difference from Multi-Racial Feminism.” Feminist Studies 2:321-331, 1996.

Tripp, Aili. "Women's Movements, Customary Law and Land Rights in Africa: The Case of Uganda." African Studies Quarterly 7, no. DATE 4: 1-19.

Tsikata, Dzodzi. Gender Training in Ghana: Politics, Issues and Tools. Accra: Woeli, 2001.

Wing, Susanna. "Women Activists in Mali: The Global Discourse on Human Rights," in Women, Activism and Globalization: Linking Local Struggles and Transnational Politics, eds. Naples and Desai. New York: Routledge, 2002, 172-188.

Yesufu, Adenike. "The Gender Dimensions of the Immigrant Experience: The Case of African-Canadian Women in Edmonton," in The African Diaspora in Canada: Negotiating Identity and Belonging, eds. Tettey and Puplampu. Calgary: The University of Calgary Press, 2005, 133-146. 